SINAI Journal of Applied Sciences 9 (2) 2020 169-182

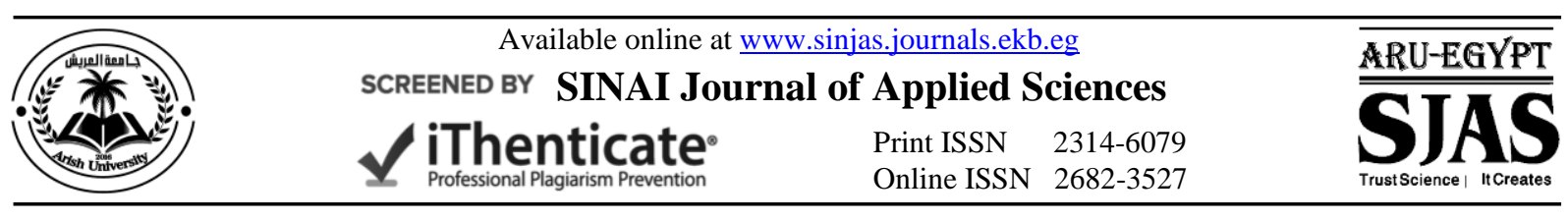

\title{
ASSESSMENTS OF ENVIRONMENTAL SENSITIVITY TO DESERTIFICATION IN BER EL-ABD AREA, NORTH SINAI, EGYPT USING MEDALUS MODEL
}

\author{
Hend H. Abd El-Hameed ${ }^{{ }^{*}}$, E.R. Marzouk ${ }^{1}$, M. R. Abdo ${ }^{1}$ and A.B. Abdelmontaleb ${ }^{2}$ \\ 1. Dept. Soil and Water, Fac. Environ. Agric. Sci., Arish Univ., Egypt. \\ 2. Dept. Soil, National Authority for Remote Sensing and Space Sci., Cairo, Egypt.
}

\section{ARTICLE INFO \\ Article history: \\ Received: $16 / 07 / 2020$ \\ Revised: $15 / 09 / 2020$ \\ Accepted: 15/09/2020 \\ Available online: 15/09/2020}

Keywords:

North Sinai,

GIS, Remote sensing,

Desertification sensitivity,

MEDALUS.

\begin{abstract}
North Sinai, desertification risk is one of the main environmental and also social and economic problems. This study aims to use geospatial information to assess the environmental sensitivity for desertification in Ber El-Abd area, North Sinai, Egypt. Based on the Mediterranean Desertification and Land Use (MEDALUS) approach and the characteristics of the study area. This model could provide a valuable quantitative assessment of environmental sensitivity to desertification. It also could support decision makers with important information that could help in protecting and sustaining natural resources. Five main indicators of desertification including soil (soil depth, soil texture, electrical conductivity, rock fragments, drainage, and calcium carbonate), climate (rainfall, evapotranspiration, and aridity index), vegetation (erosion protection, drought resistance, and plant cover), erosion (wind erosion, water erosion) and management (land use, grazing intensity as well as policy and management) were considered for estimating the environmental sensitivity to desertification. Arc-GIS 10.4.1 and ENVI 5.4 software were used for assessing the desertification sensitive index, of which the map of environmentally areas of Ber El-Abd are, North Sinai Peninsula is produced. The obtained data reveals that $47.9 \%$ of Ber El-Abd area is characterized by very sensitive areas to desertification, sensitive areas about $1.1 \%$, while the low sensitive areas only $6 \%$. The moderately sensitive areas occupies approximately $4.8 \%$ of the study area.
\end{abstract}

\section{INTRODUCTION}

Desertification is defined as "a condition of human-induced land degradation that occurs in arid, semi-arid and dry-sub humid regions and leads to a persistent decline in economic productivity of useful biota related to a land use or production system" (UNCCD, 2002). The United Nations Conference on desertification defined it as the diminution or destruction of the biological potential of the land, which could lead ultimately to the formation of desertlike conditions. This definition was modified by the United Nations Environment Programed (UNEP) as land degradation in arid, semi-arid and dry sub-humid areas resulting mainly from adverse human impact (Shalaby et al., 2004). The climatological conditions of the northern part of Sinai play an important role in shaping North Sinai area and in controlling the ecology of the area. These conditions include extreme aridity, long hot rainless summer periods and mild winters in which storms rarely occur. The northern part of Sinai is also characterized by a so called ElKhamasin storms or sandstorms. These are violent winds which blow intermittently over a period of 50 days during February and March. Generally, the prevailing climatic conditions in the North Sinai

\footnotetext{
* Corresponding author: E-mail address: hend_hh2009@yahoo.com https://doi.org/10.21608/SINJAS.2020.36002.1001

(C) 2020 SINAI Journal of Applied Sciences. Published by Fac. Environ. Agric. Sci., Arish Univ. All rights reserved.
} 
include low rainfall, high temperatures, strong wind, high evaporation and low relative humidity.

The temperatures in the North Sinai differ from one location to another according to its position from the Mediterranean Sea and the direction of winds (Hassan, 2002).

\section{Breckle et al. (2}

001) and Elnaggar (2014) show that desertification is one of the most important problems that are facing arid and semi-arid regions along the world. This phenomenon could be either human-induced or due to adverse natural conditions or both, which is common. Egypt is classified as territory susceptible to very high to high desertification sensitivity. The desertification processes existing in Egypt include; urban encroachment on expenses of arable land, wind erosion, water erosion, salinization and water logging (Rasmy et al., 2010). Saleh et al. (2018) reported that different models have been recently developed for the quantitative assessment of desertification. The Mediterranean Desertification and Land Use (MEDALUS) model is one of the most commonly used models in this regard (Basso et al., 2000; Kosmas et al., 2003). Different types of sensitivity to desertification were observed around the Mediterranean region. Most of highly sensitive areas in that region were primarily associated with low rainfall, low vegetation cover, low resistance of vegetation to drought, steepness and high soil erosion (Ali and El-Baroudy, 2008; Gad and Lotfy, 2008; Afifi et al., 2010). This model considers soil, vegetation, climate and management quality indices in the evaluation of Environmental Sensitivity Areas (ESAs) to desertification. It could be concluded that the Mediterranean Desertification and Land Use (MEDALUS) model could provide a valuable quantitative assessment of environmental sensitivity to desertification. It also could support decision makers with important information that could help in protecting and sustaining natural resources. In this model environmental sensitivity to desertification was evaluated based on four important quality indices (soil, vegetation, climate and management) that have great impact on that phenomenon. Remote sensing and GIS techniques are very helpful to collect, store, manage, retrieve, analyze, and output the huge amounts of geospatial data and field observations (Al-Khuzaie et al., 2015). The development of GIS facilitated the integration of multi sources of spatial data, which helped in the establishment and standardization of procedures used to evaluate and identify sensitive areas to desertification (Ferrara et al., 1995; Basso et al., 1998).

The aim of this study was to use MEDALUS methodology using GIS to assess and map the desertification sensitivity in Ber El-Abd area, North Sinai, depending upon the soil's characteristics, climaticdata, vegetation, erosion and management practice.

\section{MATERIALS AND METHODS}

\section{Study Area}

The studied area is located at the northern part of the Sinai Peninsula, bounded by longitudes $33^{\circ} 15^{`}$ and $32^{\circ} 45^{`}$ East, and latitudes $30^{\circ} 55^{\circ}$ and $31^{\circ} 15^{\circ}$ North, as shown in Fig. 1. The main geomorphological units in North Sinai are basin, sabkhas (dry and wet), sand dunes (high, medium and low), man-made terraces, sand sheet, salts, swamps, lake, island, sand bare, water bodies, and costal sand dunes (Fig. 2). Soils of North Sinai were classified into two orders: Aridisols and Entisols (Hassan, 2002). The studied area has typically arid and semi-arid climatic conditions (Mohamed, 2013). The maximum temperature is $31.9^{\circ} \mathrm{C}$ in Ber ElAbd station, as was recorded in August, while the minimum temperature is $18.5^{\circ} \mathrm{C}$, as was recorded in January. The mean temperature in winter ranges between $14.7^{\circ} \mathrm{C}$ to $16.6^{\circ} \mathrm{C}$ and $14.2^{\circ} \mathrm{C}$ to $16.1^{\circ} \mathrm{C}$. In summer, the mean temperature ranges between 24.4 to $24.7^{\circ} \mathrm{C}$. The soil temperature regime of the area could be 


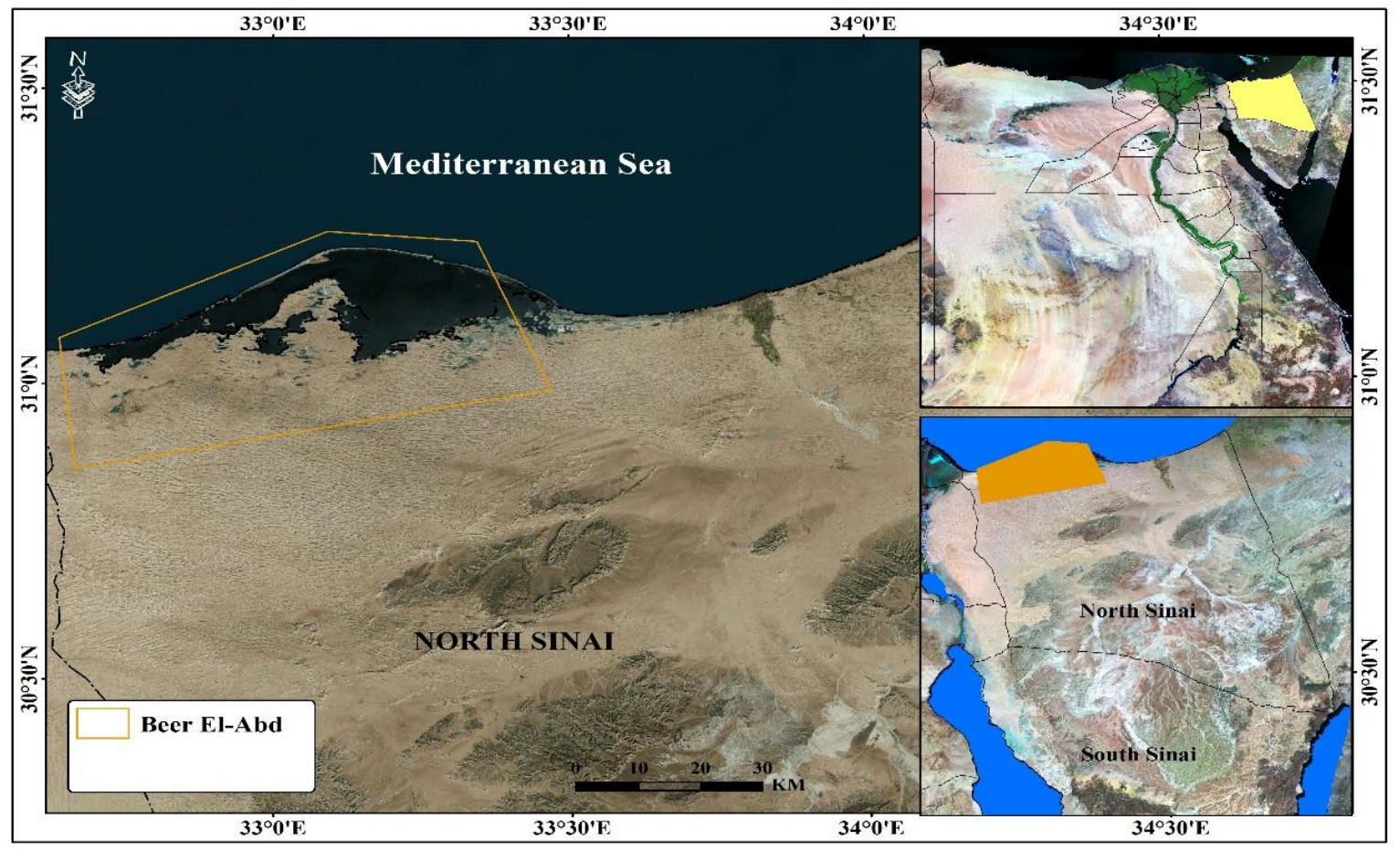

Fig. 1. Location of the study area

defined as thermic and the soil moisture regime as torric, except for the soil that has a high-water table where the soil moisture regime could be considered as aquic. The natural vegetation in the studied area is very poor, and the most striking feature in the area is its barrenness. El Salam canal is considered one of the main sources of irrigation water; it feeds the northern part of the investigated area. The source of this water is Nile water, Bahr Hadous and Serw drains, with a mixing ratio of $1: 1$ (Mohamed, 2006).

\section{Digital Image Processing}

The studied area was represented by Landsat 8 satellite images dated from 2018. The images were atmospherically corrected to calculate (Normalized Difference Vegetation Index) NDVI by equation $(\mathrm{NDVI}=(\mathrm{NIR}-\mathrm{RED}) /(\mathrm{NIR}+\mathrm{RED})$ to assess the vegetation quality index. A mosaic process was elaborated to overlay the images. (Shuttle Radar Topography Mission) SRTM Digital Elevation Model
(DEM) images were used as the source data for the elevation heights of the study. DEM has been derived from SRTM images. Slope and aspect were derived from DEM as a factor of soil quality index. The mosaic image was draped over DEM to get the feel of a natural 3D theme to get a better understanding of the physiographic units and to facilitate extracting these units.

\section{Soil Data Collection}

Around 39 soil profiles were collected, 26 soil profiles from Ragab and Reda, (2005) report and 13 soil profile from Hola, (2000). M.Sc. Thesis.

\section{Spatial assessment for desertification sensitive index (DSI)}

GIS was used five thematic indicators quantifying the environmental quality in terms of climate, soil, vegetation, land management, and erosion (Sepehr et al., 2007; Mohamed, 2013), (Table 1).

$\mathrm{DSI}=(\mathrm{SQI} \times \mathrm{VQI} \times \mathrm{CQI} \times \mathrm{MQI} \times \mathrm{EQI})^{1 / 5}$ 
Where DSI is the desertification quality index, SQI is the soil quality index, VQI is the vegetation quality index, CQI is climate quality index, MQI is the management quality index, and EQI is the erosion quality index.

\section{Soil quality index (SQI)}

The following equation was used to assessment soil quality index

$$
\mathrm{SQI}=(\mathrm{Id} \times \mathrm{It} \times \mathrm{Is} \times \mathrm{Ic} \times \mathrm{Ie} \times \mathrm{Ir} \times \mathrm{Idr})^{1 / 7}
$$

Where Id is the index of soil depth, It is the index of soil texture, Is is the index of slope gradient, Ic is the index of calcium carbonate content, Ie is the index of Electrical conductivity, Ir is the index of rock fragment and Idr is the index of drainage condition.

\section{Climate quality index (CQI)}

Climate quality is calculated according to the following equation:

$$
\mathrm{CQI}=(\mathrm{Ir} \times \mathrm{Ie} \times \mathrm{Ia})^{1 / 3}
$$

Where Ir is the index of rainfall, Ie index of evapotranspiration, and Ia is the index of aridity.

\section{Vegetation quality index (VQI)}

Vegetation quality index was calculated according the following equation:

$$
\mathrm{VQI}=(\operatorname{Iep} \times \operatorname{Idr} \times \operatorname{Ipc})^{1 / 3}
$$

Where Iep is the index of erosion protection, Idr is the index of drought resistance, and Ipc is the index of plant cover.

\section{Management quality index (MQI)}

Management quality index was calculated according to the following equation:

$$
\text { MQI }=(\mathrm{Il} \times \operatorname{Ip} \times \operatorname{Ig})^{1 / 3}
$$

Where Il is the index of land use, Ig is the index of grazing intensity, and Ip is the index of policy.

\section{Erosion quality index (EQI)}

Erosion Quality Index was calculated on the basis of the following equation:
$\mathrm{EQI}=(\text { Wind erosion } \times \text { Water erosion })^{1 / 2}$

\section{RESULTS AND DISCUSSION}

\section{Soil Quality Index}

The soil quality can be evaluated by using simple soil properties such as soil texture, electrical conductivity, rock fragment cover, soil depth, slope grade, drainage conditions as well as calcium carbonate contents. The results indicate that the classes of soil quality index were highand low-quality soils (Table 2), $57.6 \%$ $\left(1315.8 \mathrm{~km}^{2}\right)$ of the studied area is characterized by high soil quality, the low soil quality index occupies an area about $2.2 \%\left(49.7 \mathrm{~km}^{2}\right)$ of the total area as shown in Fig. 3 and Table 2.

\section{Climate Quality Index}

The rainfall, evaporation, and aridity are the main climatic attributes which contributes to the desertification processes. The result illustrated, the climate quality index was fitted under one category, which is semiarid (about 59.8\%) (Table 3 and Fig. 4). Climate quality has influence on the vulnerability of soils to desertification due to its critical impact on the growing of vegetation and soil erosion.

\section{Vegetation quality index}

Vegetation quality index is an essential factor for assessing the degree of desertification sensitivity in north Sinai. The erosion protection to the soils, drought resistance, and plant cover are the major factors affecting vegetation quality in the studied area. Remotely sensed images were used to derive NDVI as a good indicator of vegetation cover. The overall vegetation quality index of the study area was fitted into two categories (Table 5). These categories are moderately quality in about $4.7 \%$ and very low quality in about $55.1 \%$ of the study area as illustrated in Fig. 5 and Table 4. 
Table 1. Classes and factors assigned weighting index affecting desertification process

\begin{tabular}{|c|c|c|c|c|}
\hline Indicator & Sub indicator & Description & Class (threshold) & Index \\
\hline \multirow{27}{*}{ 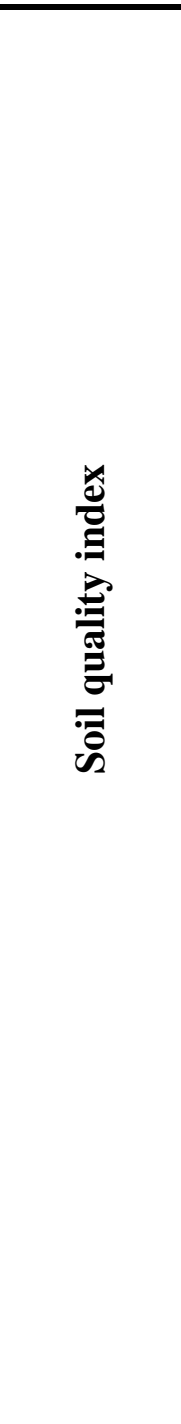 } & \multirow{4}{*}{ Soil depth } & Very deep & Depth $>1 \mathrm{~m}$ & 1.0 \\
\hline & & Moderately deep & Depth $<1$ to $0.5 \mathrm{~m}$ & 1.33 \\
\hline & & Shallow & $\begin{array}{c}\text { Depth }<0.5 \text { to } \\
0.25 \mathrm{~m}\end{array}$ & 1.66 \\
\hline & & Very shallow & Depth $<0.15 \mathrm{~m}$ & 2.00 \\
\hline & \multirow{4}{*}{ Soil texture } & Loamy sand, Sandy loam & 1 & 1.0 \\
\hline & & Loamy clay, clayey sand, sandy clay & 2 & 1.2 \\
\hline & & Clayey, clay loam & 3 & 1.6 \\
\hline & & Sandy to very sandy & 4 & 2.0 \\
\hline & \multirow{5}{*}{ Slope gradient } & Gentle & $<6 \%$ & 1.0 \\
\hline & & Not very gentle & $6-18 \%$ & 1.33 \\
\hline & & Abrupt & $19-35 \%$ & 1.66 \\
\hline & & Very abrupt & $>35 \%$ & 2.0 \\
\hline & & Very low & $<4 \mathrm{dS} / \mathrm{m}$ & 1.0 \\
\hline & \multirow{4}{*}{$\begin{array}{c}\text { Electrical } \\
\text { conductivity }\end{array}$} & Low & $4-8$ & 1.2 \\
\hline & & Moderately & $8-16$ & 1.5 \\
\hline & & Moderately high & $16-32$ & 1.7 \\
\hline & & High & $>32$ & 2.0 \\
\hline & \multirow{3}{*}{ Rock fragments } & Very stony & $>60 \%$ & 1.0 \\
\hline & & Stony & $60-20 \%$ & 1.3 \\
\hline & & Bare to slightly stony & $<20 \%$ & 2.0 \\
\hline & \multirow{4}{*}{ Drainage } & Well drained & 1 & 1.0 \\
\hline & & Moderately drained & 2 & 1.2 \\
\hline & & Poorly drained & 3 & 2.0 \\
\hline & & Non-calcareous & $<5 \%$ & 1.0 \\
\hline & Calcium & Slightly calcareous & $5-10 \%$ & 1.2 \\
\hline & carbonate & Moderately calcareous & $10-20 \%$ & 1.5 \\
\hline & & Strongly calcareous & $>20 \%$ & 2.0 \\
\hline \multirow{9}{*}{ 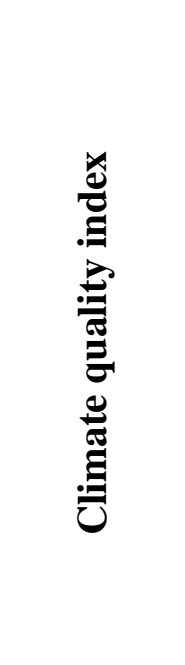 } & \multirow{3}{*}{ Rainfall (mm) } & High & $>300 \mathrm{~mm}$ & 1.0 \\
\hline & & Moderately & $150-300 \mathrm{~mm}$ & 1.33 \\
\hline & & Low & $>150 \mathrm{~mm}$ & 1.66 \\
\hline & \multirow{2}{*}{$\begin{array}{c}\text { Evapotranspirat } \\
\text { ion }(\mathrm{mm})\end{array}$} & Low & $<1,500 \mathrm{~mm}$ & 1.0 \\
\hline & & Moderately & $1,500-2,000 \mathrm{~mm}$ & 1.5 \\
\hline & $\begin{array}{c}\text { Calculated } \\
\text { according (FAO } \\
\text { Penman- } \\
\text { Monteith } \\
\text { method) }\end{array}$ & High & $>200 \mathrm{~mm}$ & 2.0 \\
\hline & \multirow{3}{*}{$\begin{array}{l}\text { Aridity index } \\
\text { (P/ETp) }\end{array}$} & Semi-arid & $\mathrm{AI} \geq 1$ & 1.0 \\
\hline & & Arid & AI $0.1-1$ & 1.5 \\
\hline & & Hyper-arid & $\mathrm{AI}<0.1$ & 2.0 \\
\hline
\end{tabular}


Table 1. Cont.

\begin{tabular}{|c|c|c|c|c|}
\hline Indicator & Sub indicator & Description & $\begin{array}{c}\text { Class } \\
\text { (threshold) }\end{array}$ & Index \\
\hline \multirow{10}{*}{ 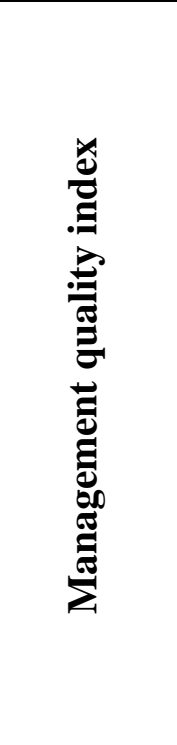 } & \multirow{4}{*}{ Land use } & Agricultural lands & 1 & 1 \\
\hline & & Rangelands & 2 & 1.3 \\
\hline & & Poor and degraded & 3 & 1.6 \\
\hline & & Bare lands & 4 & 2 \\
\hline & \multirow{3}{*}{$\begin{array}{l}\text { Grazing } \\
\text { intensity }\end{array}$} & Low & $<1$ & 1.0 \\
\hline & & Moderate & $1-2.5$ & 1.5 \\
\hline & & High & $>2.5$ & 2 \\
\hline & \multirow{3}{*}{$\begin{array}{l}\text { Policy and } \\
\text { management }\end{array}$} & $\begin{array}{c}\text { Complete: }>75 \% \text { of the area under } \\
\text { protection }\end{array}$ & 1 & 1.0 \\
\hline & & $\begin{array}{c}\text { Partial: } 25-75 \% \text { of the area under } \\
\text { protection }\end{array}$ & 2 & 1.5 \\
\hline & & $\begin{array}{c}\text { Incomplete: }<25 \% \text { of the area under } \\
\text { protection }\end{array}$ & 3 & 2.0 \\
\hline \multirow{10}{*}{ 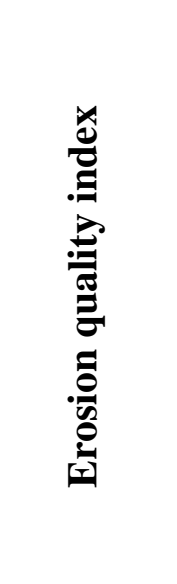 } & \multirow{5}{*}{ Wind erosion } & Very low & 1 & 1 \\
\hline & & Low & 2 & 1.2 \\
\hline & & Moderate & 3 & 1.5 \\
\hline & & High & 4 & 1.7 \\
\hline & & Very high & 5 & 2 \\
\hline & & Very low & 1 & 1 \\
\hline & & Low & 2 & 1.2 \\
\hline & Water erosion & Moderate & 3 & 1.5 \\
\hline & & High & 4 & 1.7 \\
\hline & & Very high & 5 & 2 \\
\hline & & High & 1 & 1.0 \\
\hline & Erosion & Moderately & 2 & 1.33 \\
\hline 肴 & protection & Low & 3 & 1.66 \\
\hline. & & Very low & 4 & 2 \\
\hline 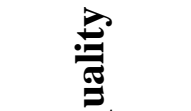 & & $\begin{array}{l}\text { Gardens, orchards, } \\
\quad \text { rangelands }\end{array}$ & 1 & 1.0 \\
\hline 䏤 & resistance & $\begin{array}{l}\text { Permanent grassland, annual crops and } \\
\text { grasslands }\end{array}$ & 2 & 1.5 \\
\hline$\vec{\Delta}_{0}$ & & Bare land & 3 & 2.0 \\
\hline$\nu^{\circ ँ}$ & & High & $>35 \%$ & 1.0 \\
\hline & Plant cover & Low & $10-35 \%$ & 1.5 \\
\hline & & Very low & $<10 \%$ & 2 \\
\hline
\end{tabular}


Table 2. Soil quality index of the studied area

\begin{tabular}{lccccc}
\hline SQI classes & Score & Area $\left(\mathbf{K m}^{2}\right)$ & Area $(\mathbf{F e d})$ & Area (ha) & Area of total (\%) \\
\hline High quality & $<1.2$ & 1315.8 & 315190.1 & 750468 & 57.6 \\
Low quality & $>1.5$ & 49.7 & 11839.7 & 28190 & 2.2 \\
Reference terms & & 916.8 & 216371.2 & 515180 & 40.2 \\
Total & & 2282.3 & 543401.0 & 1293838 & 100 \\
\hline
\end{tabular}

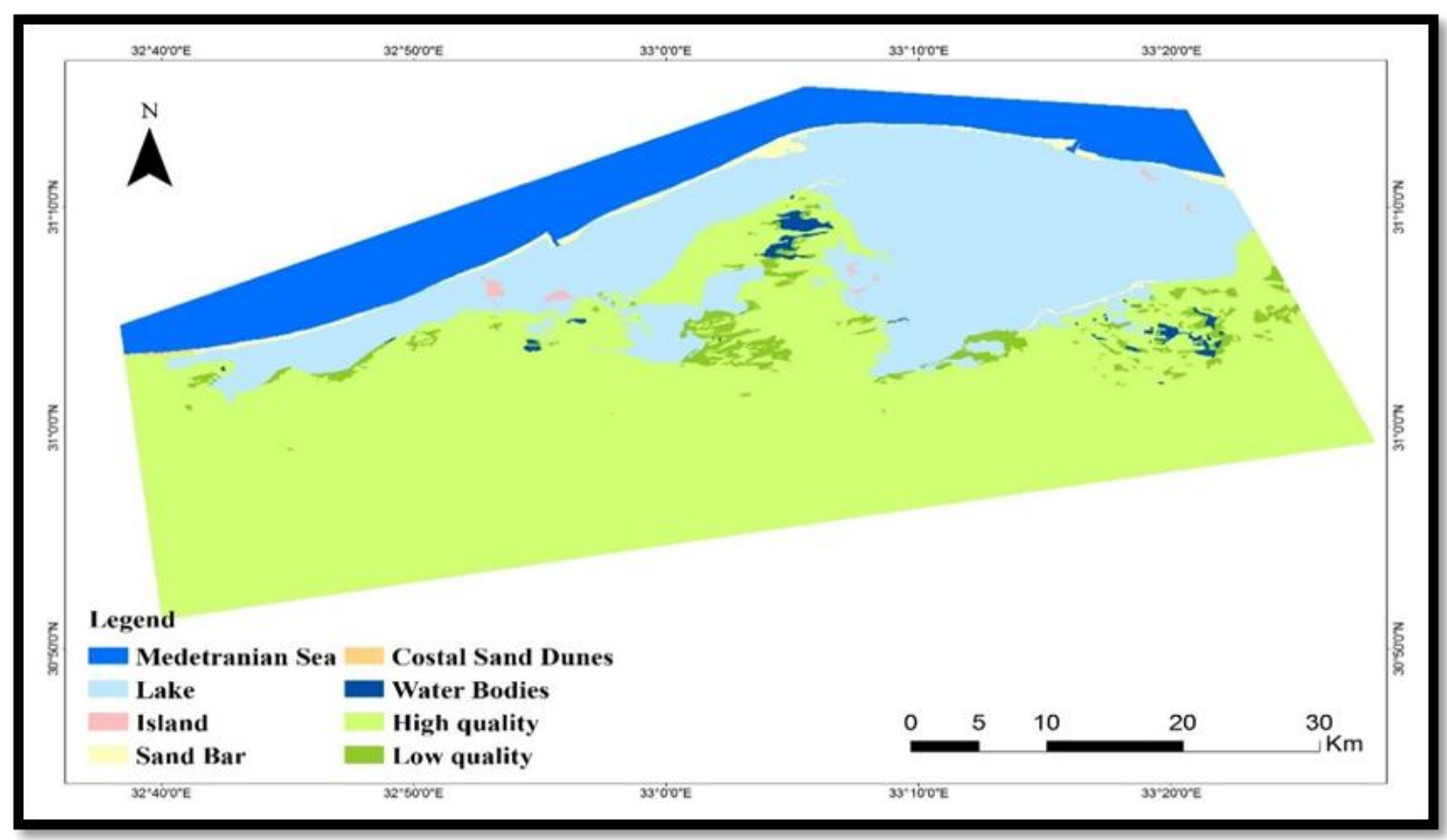

Fig. 3. Classes of Soil quality index in the studied area

Table 3. Climate quality classes of the studied area

\begin{tabular}{lccccc}
\hline CQI classes & Score & Area $\left(\mathbf{K m}^{2}\right)$ & Area $($ Fed) & Area (ha) & Area of total (\%) \\
\hline Semi-arid & $1.2-1.4$ & 1365.5 & 327029.8 & 778658 & 59.8 \\
Arid & $1.4-1.6$ & - & - & - & - \\
Hyper-arid & $>1.6$ & - & - & - & - \\
Reference terms & & 916.8 & 216371.0 & 515179 & 40.2 \\
Total & & 2282.2 & 543401.0 & 1293838 & 100 \\
\hline
\end{tabular}




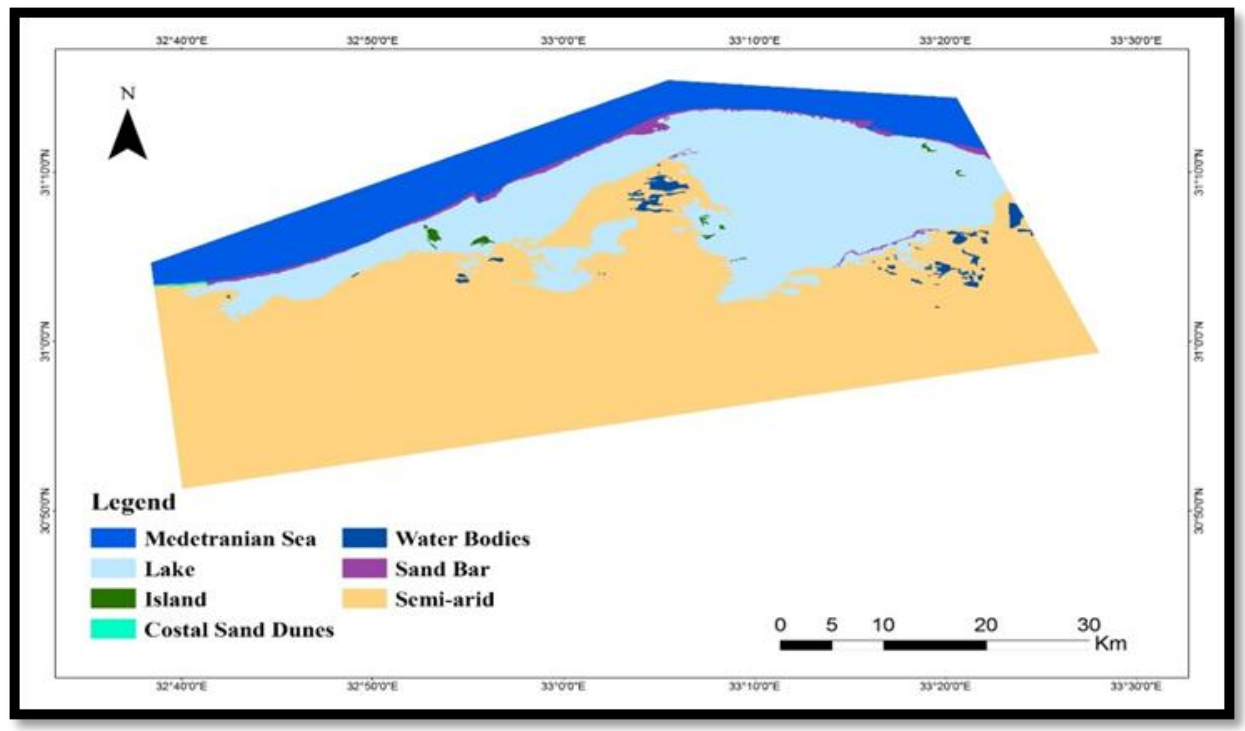

Fig. 4. Classes of Climate quality index classes of the studied area.

Table 4. Vegetation quality classes in the studied area

\begin{tabular}{lccccc}
\hline VQI classes & Score & Area $\left(\mathbf{K m}^{2}\right)$ & Area $($ Fed) & Area (ha) & Area of total (\%) \\
\hline High quality & $<1.2$ & 0 & 0 & 0 & 0 \\
Moderate quality & $1.2-1.4$ & 107.8 & 26165.9 & 62301 & 4.7 \\
Low quality & $1.4-1.6$ & 0 & 0 & 0 & 0 \\
Very low quality & $>1.6$ & 1257.7 & 299457.7 & 713009 & 55.1 \\
Reference terms & & 916.8 & 217777.4 & 518528 & 40.2 \\
Total & & 2282.3 & 543401.0 & 1293838 & 100 \\
\hline
\end{tabular}

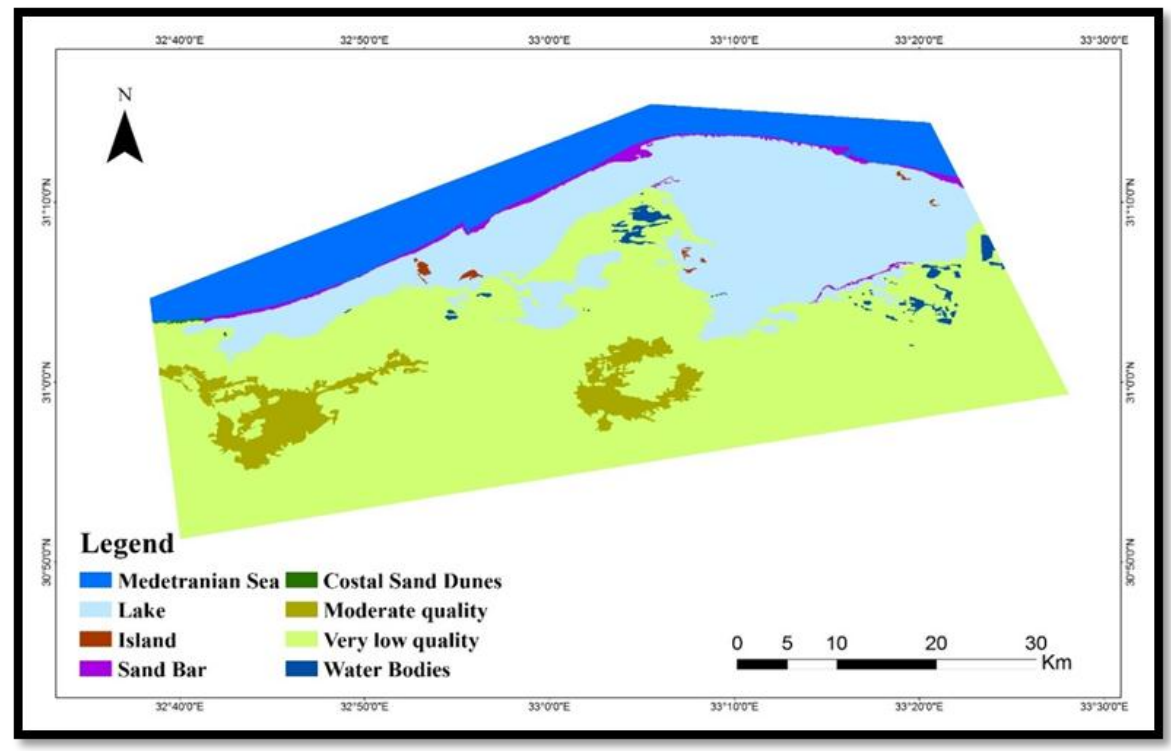

Fig. 5. Vegetation quality index classes of the studied area 
Table 5. Management quality classes in the studied area

\begin{tabular}{lccccc}
\hline MQI classes & Score & Area $\left(\mathbf{K m}^{2}\right)$ & Area (Fed) & Area (ha) & Area of total (\%) \\
\hline High quality & $1.0-1.3$ & 310.7 & 73986.6 & 176162 & 13.6 \\
Moderate quality & $1.3-1.5$ & 688.0 & 163816.6 & 390047 & 30.1 \\
Low quality & $>1.5$ & 366.7 & 87300.9 & 207863 & 16.1 \\
Reference terms & & 916.8 & 218296.8 & 519765 & 40.2 \\
Total & & 2282.3 & 543401.0 & 1293838 & 100 \\
\hline
\end{tabular}

\section{Management Quality Index}

Management quality index included land use, grazing intensity, and policy, which were clearly important factors controlling the desertification process. The result indicated that the management quality index of the study area was fit into three categories as demonstrated in Table 5. These categories are high, moderate and low in about 13.6, 30.1 and $16.1 \%$ of the studied area, respectively (Table 5 and Fig. 6).

\section{Erosion Quality Index}

Erosion plays an important role in desertification sensitivity in the northern Sinai region, which is characterized by a high and moderate erosion quality index due to the effect of morphology and relief, wind velocity, soil characteristics, and plant cover. The result indicated that the overall erosion quality index of the study area was fitted into three categories (Table 6). These categories are high, moderate and low quality in about 11.3, 39.8 and $8.9 \%$ respectively from the study area as illustrated in Fig. 7 and Table 6.

\section{Desertification Sensitive Index (DSI) in the Studied Area}

The integration of soil parameters, climate condition, vegetation cover, management, and erosion rates were considered to derive DSI. Based on the results of the abovementioned quality indices, SQI, CQI, VQI,
MQI and EQI in the study area were fitted into four environmental sensitivity classes to desertification. These classes are very sensitive areas (represent about $47.9 \%$ of the study area), sensitive areas (represent about $1.1 \%$ of the study area), moderate sensitive areas (represent about $4.8 \%$ of the study area) and low Sensitive areas (represent about $6 \%$ of the study area), as illustrated in Fig. 8 and Table 7.

\section{Conclusions}

The MEDALUS model is very valuable method in assessing the desertification phenomena in arid and semi-arid regions. In this study, we apply the MEDALUS methodology using GIS to assess and map the desertification sensitivity in the study area depending upon the soil's characteristics, climatically data, erosion, vegetation, and management practice. Remote sensing data and GIS tools is very important in identifying areas where sensitivity is increasing over time. This work covered the highlights and overviews on severity areas in the Ber El-Abd, North Sinai where it shows a part, about $47.9 \%$, of the studied area which is susceptible to desertification due to low vegetation cover, soil quality, mismanagement, climate condition, and wind erosion. Therefore, these area of North Sinai needs great efforts from the Egyptian government to overcome these phenomena through using effective management and policies to combat desertification. 


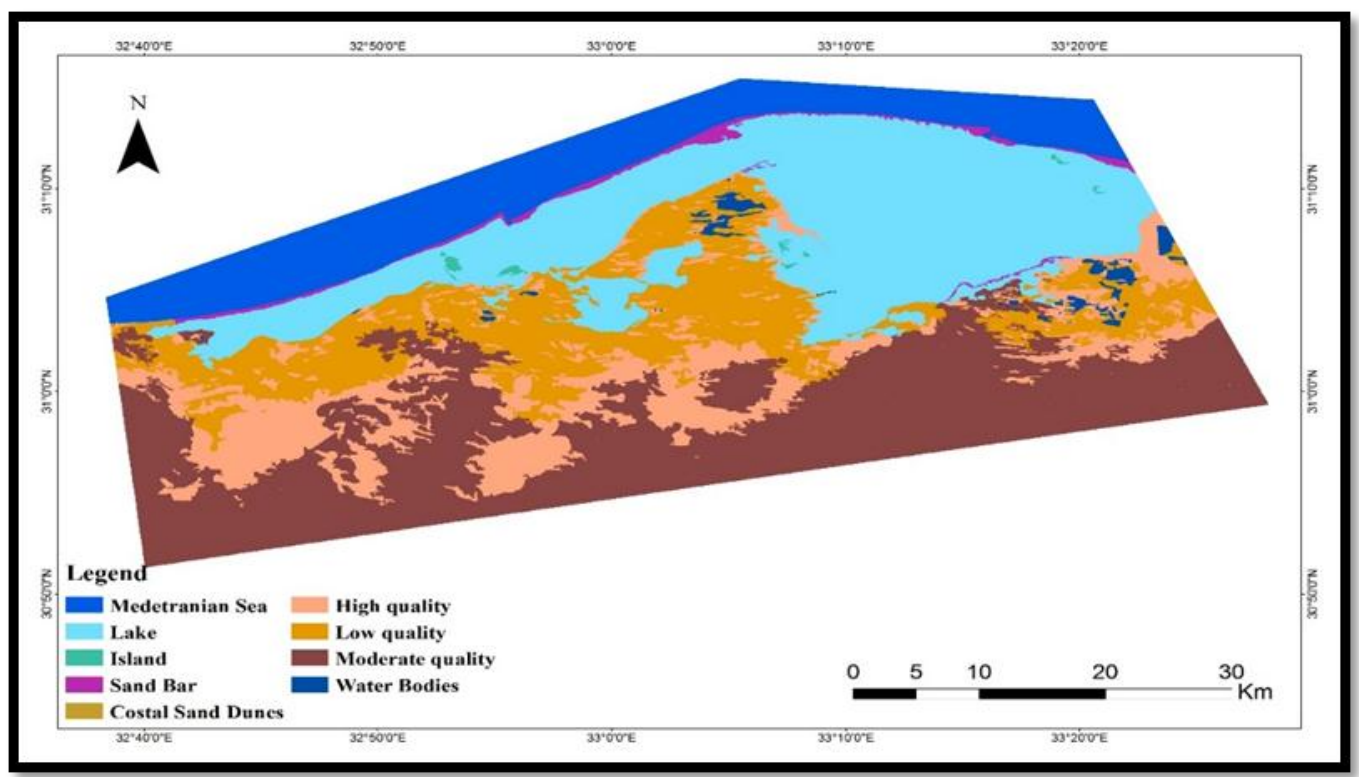

Fig. 6. Management quality index classes of the studied area

Table 6. Erosion quality classes in the studied area

\begin{tabular}{lccccc}
\hline EQI classes & Score & Area $\left(\mathbf{K m}^{2}\right)$ & Area $($ Fed) & Area (ha) & Area of total (\%) \\
\hline Low quality & $<1.2$ & 202.4 & 48199.9 & 114764 & 8.9 \\
Moderate quality & $1.2-1.6$ & 904.5 & 215362.3 & 512778 & 39.6 \\
High quality & $>1.6$ & 258.5 & 61541.9 & 146531 & 11.3 \\
Reference terms & & 916.8 & 218296.8 & 519765 & 40.2 \\
Total & & 2282.3 & 543401.0 & 1293838 & 100 \\
\hline
\end{tabular}

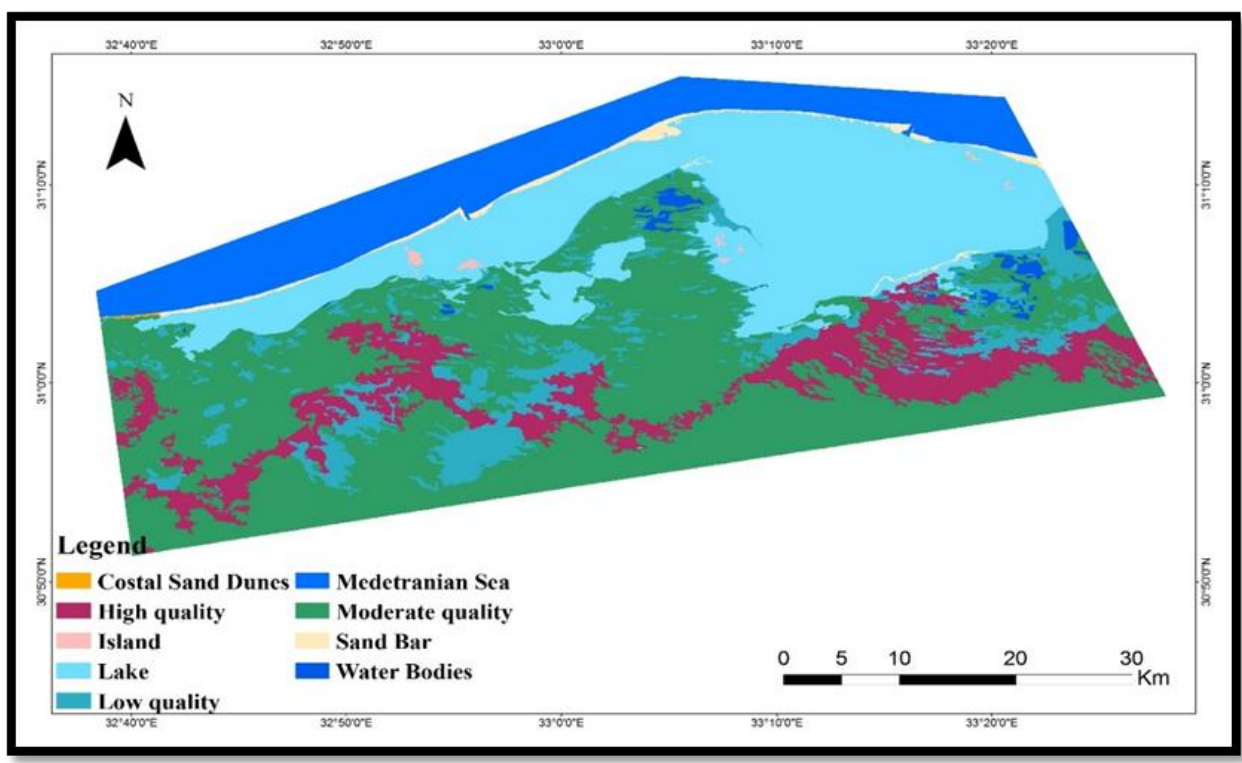

Fig. 7. EQI classes of the studied area 
Table 7. Environmentally sensitive areas

\begin{tabular}{lccccc}
\hline DSI class & Score & Area $\left(\mathbf{K m}^{2}\right)$ & Area $($ Fed) & Area (ha) Area of total (\%) \\
\hline Low sensitive areas & $1.2-1.3$ & 137.4 & 32702.5 & 77865 & 6.0 \\
Moderately sensitive areas & $1.3-1.4$ & 109.9 & 26165.9 & 62301 & 4.8 \\
Sensitive areas & $1.4-1.6$ & 25.8 & 6134.4 & 14606 & 1.1 \\
Very sensitive areas & $>1.6$ & 1092.5 & 260114.1 & 619332 & 47.9 \\
Reference term & & 916.8 & 218284.1 & 519734 & 40.2 \\
Total & & 2282.3 & 543401.0 & 1293838 & 100 \\
\hline
\end{tabular}

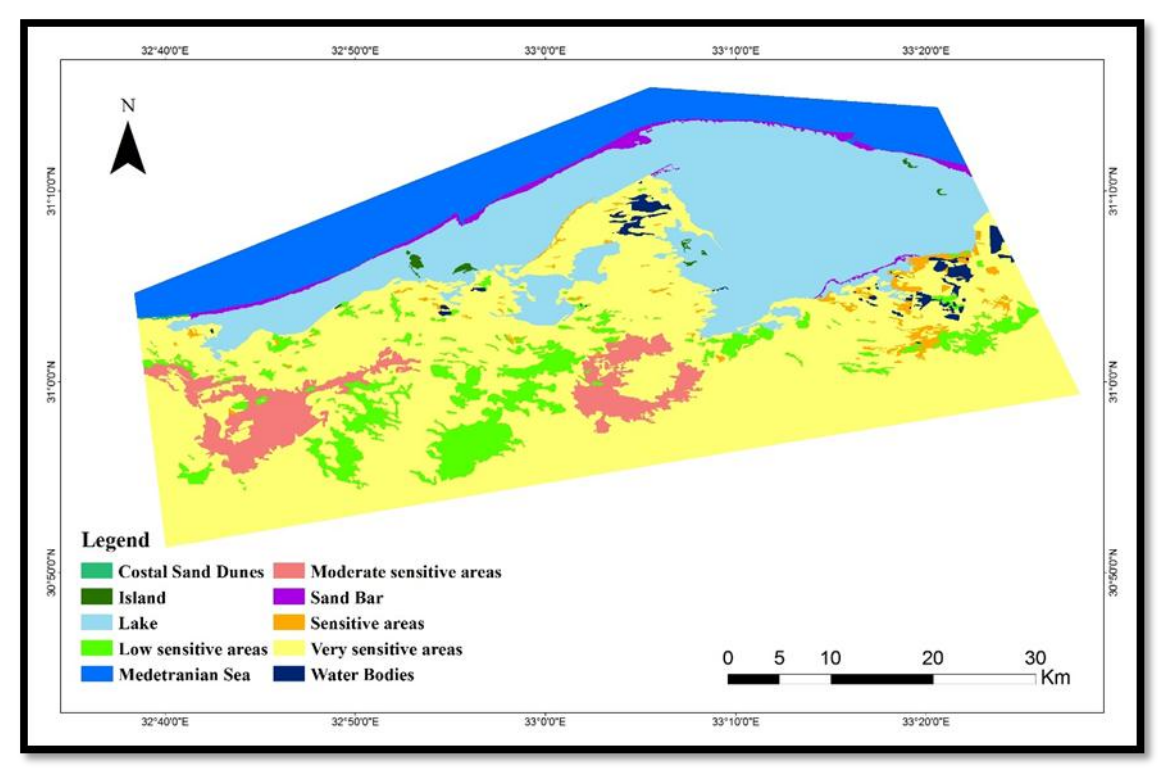

Fig. 8. DSI map of study area

\section{REFERENCES}

Afifi, A.; Gad, A. and Refat, A. (2010). Use of GIS and remote sensing for environmental sensitivity assessment of North coastal part, Egypt. J. Ame. Sci., 6 (11): 632-646.

Ali, R.R. and El-Baroudy, A.A. (2008). Use of GIS in mapping the environmental sensitivity to desertification in Wadi El Natrun Depression, Egypt. Aust. J Basic and Appl. Sci., 2(1): 157-164.

Al-Khuzaie, M.M.; Elnaggar, A.A., Mowafy, M. and El Sheikha, Z.M. (2015). Assessments of Environmental Sensitivity to Desertification in North
Sinai, Egypt Using Remote Sensing and GIS Techniques. Int. J. Sci. and Eng. Res., 6 (7). ISSN 2229-5518.

Basso F., Bove E., Dumontet S., Ferrara A., Pisante M., Quaranta G., and Taberner M. (2000): Evaluating environmental sensitivity at the basin scale through the use of Geographic Information Systems and remote sensed data. An Example Covering the Agri Basin (Southern Italy). Catena 40:19-35.

Basso, F.; Bellotti, A.; Bove, E.S. Faretta, A.; Ferrara, G.; Mancino, M.; Pisante, G.Quaranta, and Taberner, $M$. (1998): Degradation processes in the Agri Basin: evaluating environmental 
sensitivity to desertification at basin scale. Proceedings International Seminar on 'Indicator for Assessing Desertification in the Mediterranean'. Porto Torres, Italy 18 - 20 September. Edited by G. Enne, M. D'Angelo, C. Zanolla. Supported by ANPA via Brancati 48 - 00144 Roma. pp 131-145.

Breckle, S.W.; Veste, M., and Wucherer, W., (2001): Sustainable Land Use in Deserts. Springer-Verlag Berlin. Heidelberg Germany. eBook ISBN: 978-3-642-59560-8.

Elnaggar, A. A. (2014): Environmental Sensitivity to Desertification in Bahariya Oasis, Egypt. $11^{\text {th }}$ Int. Conf. of the Egyptian Soc. (ESSSJ), Fac. of Agric., Kafer El-Sheikh Univ., Egypt.

Ferrara, A., M. Pisante, A. R. Harrison and M. Taberner, (1995): The use of spatial relationship analysis to study the Agri-basin with remotely sensed images. MEDALUS II Final Report, King's College, London, pp.67-83.

Gad, A., and Lotfy, I. (2008): Use of remote sensing and GIS in mapping the environmental sensitivity areas for desertification of Egyptian territory. Earth Discussions, 3(2), 41-85.

H. and Sh, N. (2000). Land use Mapping for Selected areas of El-Salam Canal Command- Sinai, using remote sensing and GIS. M.Sc., Thesis Fac. Agric., Cairo Univ., Egypt.

Hassan, M.A., (2002): Environmental studies on coastal zone soils of the north Sinai Peninsula (Egypt) using remote sensing techniques. Ph.D. Soil and Water Dept., Fac. of Agri., SCU, Ismailia, Egypt.

Kosmas, C.; Ferrara, A.; Briasouli, H. and Imeson, A. (2003). Methodology for mapping environmentally sensitive areas (ESAs) to desertification. Mediterranean Desertification and Land Use (MEDALUS), Europ. Union 18882, 31-47 ISBN 92-828-6349-2
Mohamed, E.S. (2006). Optimum land use planning for some newly reclaimed soils in west of Suez Canal area using remote sensing techniques. M.Sc. Thesis, Univ., Egypt.

Mohamed, E.S. (2013). Spatial assessment of desertification in north Sinai using modified MEDLAUS model. Arab J Geosci., 6:4647-4659 DOI 10.1007/ s12517-012-0723-2.

Ragab, M. and Reda, M. (2005). Maximizing of land water suitability in Bir El Abd region El-Salam Canal basin. Final report (phase I) Sand Dunes Encroachment, Suez Canal Univ.

Rasmy, M.; Gad, A.; Abdelsalam, H. and Siwailam, M. (2010). A dynamic simulation model of desertification in Egypt. Egypt. J. Remote Sensing and Space Sci., 13: 101-111.

Saleh, A.M.; Belal, A.A. and Jalhoum, M. (2018). Quantitative Assessment of Environmental Sensitivity to Desertification in Sidi Abdel-Rahman area, Northern West Coast Egypt. Egypt. J. Soil Sci., 58 (1): $13-26$.

Sepehr, A.; Hassanli, A.M.; Ekhtesasi, M.R. and Jamali, J.B. (2007). Quantitative assessment of desertification in south of Iran using MEDALUS method. Environ Monit. Assess., 134: 243-254.

Shalaby, A.; Aboel Ghar, M. and Tateishi, R. (2004). Desertification Impact Assessment in Egypt Using Low Resolution Satellite Data and GIS. Intern. J. Environ. Studies, 61 (4): 375383.

UNCCD (2002). United Nations Convention to Combat Desertification in those countries experiencing serious drought and/or desertification, particularly in Africa. Text with annexes. Secretariat of the UNCCD, Bonn, 76. 


$$
\text { الملخص العربي }
$$

تقييم الحساسية البيئية للتصحر في منطقة بئر العبد، شمال سيناء، مصر باستخدام نموذج ميالس

هند حسين عبد الحميد1، عزت رشاد مرزوق1، محمد رجب عبدها' عبد العزيز بلال عبد المنطب2

$$
\text { 1- قسم الأر اضي و المياه، كلية العلوم الزر اعية البيئية، جامعة العريش، مصر . }
$$

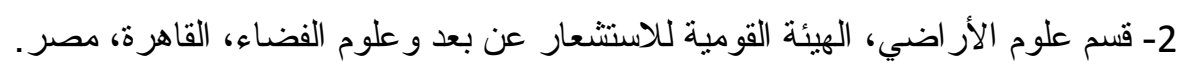

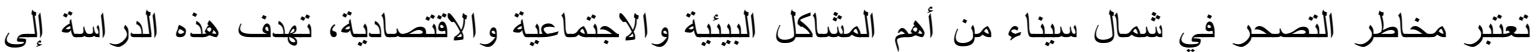

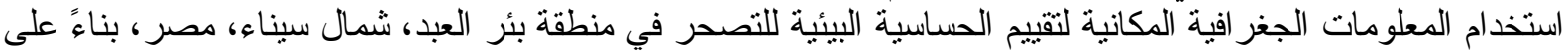

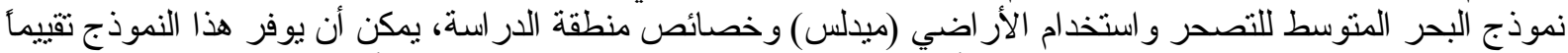

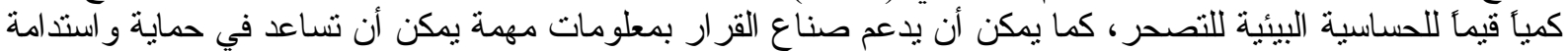

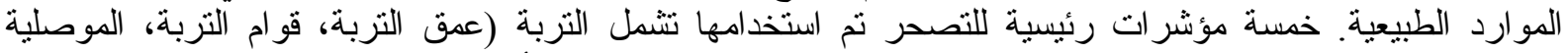

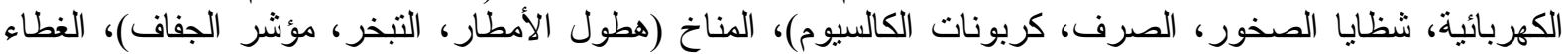

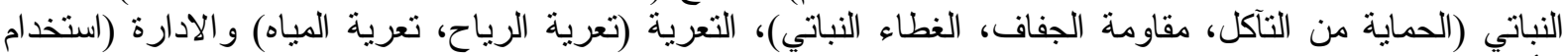

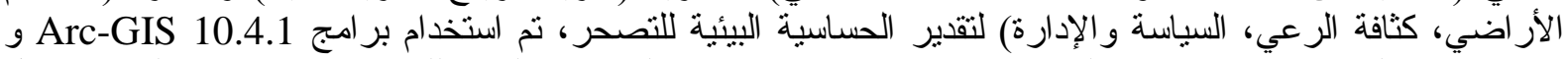
ENVI 5.4

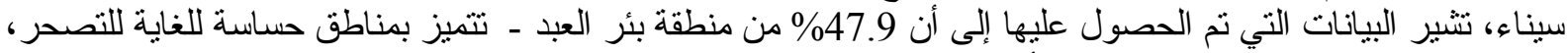

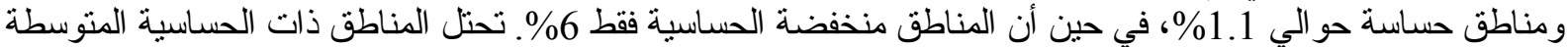
حو الي 4.8\% من مساحة الدر اسة. الكلمات الاسترشادية: شمال سيناء، نظم المعلومات الجغر افية، الاستشعار عن بعد، حساسية التصحر ، ميدلس. 
